ALTRUIS

Journal of Community Services

2020, Vol. 1, No. 1, 56-70
ISSN 2721- 415X (Online)

ISSN 2721- 4168 (Print)

ejournal.umm.ac.id/index.php/altruis

\title{
Psikoedukasi Perilaku Seksual Remaja
}

\section{Safe Sexual Behavior Seminar on Teenagers}

\author{
Citra Ayi Safitri ${ }^{1}$, Bintang Sasmita Wicaksana ${ }^{2}$ \\ Fakultas Psikologi, Universitas Muhammadiyah Malang \\ Email: ${ }^{1}$ citra.ayu.safitri@gmail.com, ${ }^{2}$ bwicaksana@gmail.com
}

\begin{abstract}
ABSTRAK Pada masa remaja informasi tentang masalah seksual sudah seharusnya mulai diberikan, agar remaja tidak mencari informasi dari orang lain atau dari sumber-sumber yang tidak jelas. Pemberian informasi masalah seksual menjadi penting terlebih lagi mengingat remaja berada dalam potensi seksual yang aktif, karena berkaitan dengan dorongan seksual yang dipengaruhi hormon dan sering tidak memiliki informasi yang cukup mengenai aktivitas seksual mereka sendiri. Tentu saja hal tersebut akan sangat berbahaya bagi perkembangan jiwa remaja bila ia tidak memiliki pengetahuan dan informasi yang tepat mengenai perilaku seksual. Berbagai hasil penelitian menunjukkan bahwa seiring dengan arus globalisasi informasi dan teknologi yang terus berjalan, terjadi perubahan besar pada norma seks, utamanya pada remaja. Hasil penelitian di Amerika pada tahun 2004 bahwa penayangan seks di televisi telah mempengaruhi perilaku seks remaja, hasil penelitian menunjukkan bahwa terdapat 20\% remaja usia 17 tahun telah melakukan intercourse, 40\% remaja usia 17 tahun mulai meraba payudara, dan terdapat 20\% remaja usia 17 tahun meraba genetalia (Diene M, 2002). Subyek dalam kegiatan ini adalah siswa-siswi SMK Muhammadiyah 2 Malang. Hasil dari pengabdian ini menggambarkan bahwa siswa-siswi SMK sangat tertarik dengan kegiatan ini dan melalui pengabdian ini siswa-siswi dapat memahami makna pacaran dan mengetahui cara yang efektif untuk mengendalikan perilaku seksual.
\end{abstract}

KATA KUNCI Psikoedukasi, Perilaku Seksual Remaja

\begin{abstract}
In adolescence information about sexual problems should begin to be given, so that adolescents do not seek information from other people or from unclear sources. Provision of information about sexual problems becomes even more important considering that adolescents are in an active sexual potential, because it is related to sex drive that is influenced by hormones and often do not have enough information about their own sexual activity. Of course this will be very dangerous for the development of adolescent soul if he does not have the right knowledge and information about sexual behavior. Various research results show that along with the current globalization of information and technology that continues to run, there have been major changes in sexual norms, especially in adolescents. The results of research in America in 2004 that showing sex on television has influenced adolescent sexual behavior, the results showed that there are $20 \%$ of 17-year-old adolescents have intercourse, $40 \%$ of 17-year-old adolescents begin to touch the breasts, and there are $20 \%$ of adolescents aged 17 years of palpating genetalia (Diene M., 2002). The subjects in this activity were students of SMK Muhammadiyah 2 Malang. The results of this dedication illustrate that SMK students are very interested in this activity and through this dedication students can understand the meaning of courtship and know effective ways to control sexual behavior.
\end{abstract}

KEYWORDS Psychoeducation, Adolescent Sexual Behavior 
Berita Ariel, Luna dan Cut Tari terkait dengan video mesumnya tidak akan dapat hilang begitu saja, apalagi video tersebut sudah masuk ke dunia maya, siapa pun akan dapat mengakses dan menyaksikan termasuk para remaja. Kasus tersebut dapat dimaknai sebagai peringatan bahwa perilaku seksual harus mendapat perhatian yang serius terutama dikalangan remaja.

Pada masa remaja rasa ingin tahu terhadap masalah seksual sangat penting dalam pembentukan hubungan baru yang lebih matang dengan lawan jenis. Padahal pada masa remaja informasi tentang masalah seksual sudah seharusnya mulai diberikan, agar remaja tidak mencari informasi dari orang lain atau dari sumber-sumber yang tidak jelas. Pemberian informasi masalah seksual menjadi penting terlebih lagi mengingat remaja berada dalam potensi seksual yang aktif, karena berkaitan dengan dorongan seksual yang dipengaruhi hormon dan sering tidak memiliki informasi yang cukup mengenai aktivitas seksual mereka sendiri. Tentu saja hal tersebut akan sangat berbahaya bagi perkembangan jiwa remaja bila ia tidak memiliki pengetahuan dan informasi yang tepat mengenai perilaku seksual.

Memasuki milenium baru ini sudah selayaknya bila orangtua dan kaum pendidik bersikap lebih tanggap dan arif dalam menjaga serta mendidik anak ataupun remaja, agar lebih berhati-hati terhadap gejalagejala sosial, terutama yang berkaitan dengan masalah seksual yang berlangsung saat ini. Seiring perkembangan yang terjadi sudah saatnya pemberian penerangan dan pengetahuan masalah seksualitas pada anak dan remaja ditingkatkan.

Pandangan sebagian besar masyarakat yang menganggap seksualitas merupakan suatu hal yang alamiah, yang nantinya akan diketahui dengan sendirinya setelah mereka menikah sehingga dianggap suatu hal yang tabu untuk dibicarakan secara terbuka, nampaknya secara perlahan-lahan harus diubah. Sudah saatnya pandangan semacam ini harus diluruskan agar tidak terjadi hal-hal yang tidak diinginkan dan membahayakan bagi anak dan remaja sebagai generasi penerus bangsa. Remaja yang hamil di luar nikah, aborsi, penyakit kelamin, dll, adalah contoh dari beberapa kenyataan pahit yang sering terjadi pada remaja sebagai akibat pemahaman yang keliru mengenai seksualitas.

Berbagai hasil penelitian menunjukkan bahwa seiring dengan arus globalisasi informasi dan teknologi yang terus berjalan, terjadi perubahan besar pada norma seks, terutama pada remaja. Hasil penelitian di Amerika pada tahun 2004 bahwa penayangan seks di televisi telah memengaruhi perilaku seks remaja, hasil penelitian menunjukkan bahwa terdapat $20 \%$ remaja usia 17 tahun telah melakukan intercourse, $40 \%$

\section{ALTRUIS}


remaja usia 17 tahun mulai meraba payudara, dan terdapat 20\% remaja usia 17 tahun meraba genetalia (Diene M., 2002).

Berdasarkan sumber dari Hanifah (2000), bahwa beberapa hasil penelitian di Indonesia menunjukan adanya penurunan batas usia hubungan seks pertama kali. Menurut Iskandar (1998) sebanyak 18\% responden di Jakarta berhubungan seks pertama di bawah usia 18 tahun dan usia termuda 13 tahun. Sedangkan menurut Utomo (1998), menyatakan bahwa remaja Manado yang sudah aktif secara seksual, melakukan hubungan seks pertama pada usia dibawah 16 tahun sebanyak $56,8 \%$ pada remaja pria dan $33,3 \%$ pada remaja putri (dalam Sarwono, 2007).

Dr. Boyke Dian Nugraha, pakar seks dan spesialis Obstetri dan Ginekologi, menyatakan bahwa penyebabnya antara lain maraknya pengedaran gambar dan VCD porno, kurangnya pemahaman akan nilainilai agama, keliru dalam memaknai cinta, minimnya pengetahuan remaja tentang seksualitas serta belum adanya pendidikan seks secara reguler hingga formal di sekolah. Itu sebabnya informasi tentang makna hakiki cinta dan adanya kurikulum kesehatan reproduksi di sekolah mutlak diperlukan (Pasti, 2008).

Dengan pengetahuan yang sangat terbatas, maka sangatlah mungkin jika membuat mereka salah dalam bersikap dan kemudian mempunyai perilaku terhadap seksualitas. Perilaku Seksual Remaja Kota Semarang tahun 2006, menunjukkan usia pertama kali pacaran adalah 1217 tahun $68,2 \%$ lebih banyak dari pada usia $17-24$ tahun $31,2 \%$ dan aktivitas pacaran sampai dengan intercourse $6,2 \%$ dibanding dengan cara yang lain. Usia pertama kali melakukan intercourse, persentase paling besar adalah pada usia 18-20 tahun. Pasangan yang melakukan hubungan seksual intercourse lebih dari 4 kali pada 3 bulan terakhir 45\%, tempat melakukannya $41 \%$ di rumah sendiri atau pacar, alasan melakukan intercourse karena wujud ungkapan sayang 51\% (Pilar DKT, 2006).

Begitu juga problematika yang dialami remaja di SMK Muhammadiyah 2 Malang, bahwa pihak sekolah merasa kesulitan mengontrol perilaku seksual remaja ketika mereka di luar sekolah, apalagi akses informasi dan internet begitu cepat dan mudah untuk digunakan pada hal-hal yang negatif, seperti mengakses film porno.

Selain itu, kebanyakan remaja SMK Muhammadiyah 2 Malang juga memilki pacar, hal ini membuat pihak sekolah merasa kesulitan untuk memonitor dan mengontrol perilaku seksual mereka sehingga perlu mendapat pendidikan seksual.

Rasa ingin tahu terhadap masalah seksual pada remaja sangat penting dalam pembentukan hubungan baru yang lebih matang dengan 
lawan jenis. Pada masa remaja, informasi tentang masalah seksual sudah seharusnya mulai diberikan supaya remaja tidak mendapatkan informasi yang salah dari sumber-sumber yang tidak jelas. Pemberian informasi masalah seksual menjadi penting terlebih lagi mengingat remaja berada dalam potensi seksual yang aktif, karena berkaitan dengan dorongan seksual yang dipengaruhi hormon dan tidak cukupnya informasi mengenai aktifitas seksual mereka sendiri. Tentu saja hal tersebut akan sangat berbahaya bagi perkembangan jiwa remaja bila tidak didukung dengan pengetahuan dan informasi yang tepat.

Pengetahuan remaja tentang seks masih sangat kurang. Faktor ini ditambah dengan informasi keliru yang diperoleh dari sumber yang salah, seperti mitos seputar seks, VCD porno, situr porno di internet, dan lainnya akan membuat pemahaman dan persepsi anak tentang seks menjadi salah. Pendidikan seksual dalam arti luas yang meliputi berbagai aspek yang berkaitan dengan seks, diantaranya aspek biologis, psikologis, agama, nilai sosiokultur dan moral. Oleh karena itu, melalui pendekatan psikoedukasi ini, remaja akan mendapatkan pengetahuan dan pemahaman yang relevan mengenai pendidikan seksualitas.

\section{MATERI DAN METODE PELAKSANAAN \\ Kerangka Pemecahan Masalah}

Sebagaimana permasalahan di atas, maka solusi yang ditawarkan adalah sebagai berikut;

1. Metode pendekatan Iptek bagi Masyarakat (IbM) yang digunakan adalah melalui psikoedukasi, yaitu memberikan pendidikan psikologis (psikoedukasi) sehingga diharapkan para remaja lebih memahami dan siap serta mampu mengontrol diri dalam menghadapi arus globalisasi informasi dan pergaulan bebas.

2. Metode yang digunakan dalam kegiatan ini terdiri dari dua bagian, yaitu; (1) Asesmen awal, dilakukan dengan metode Focus Group Discussion (FGD) dan kuesioner. Dalam kegiatan ini diawali dengan eksplorasi pengetahuan dan pengalaman mengenai perilaku seksual remaja, cara ini dilakukan dengan metode brainstorming, kemudian dilanjutkan dengan FGD (Focus Group Discusion) untuk menggali pemahaman remaja mengenai seksualitas. Kuesioner diberikan untuk mengidentifikasi sejauhmana perilaku seksual remaja. (2) Psikoedukasi, dilakukan dengan teknik ceramah, tanya jaawab/dialog interaktif, studi kasus tentang perilaku remaja, kemudian peserta diajak presentasi, diskusi, tanya jawab dan diakhiri pemberian feed back dari fasilitator. Selain itu, para peserta diajarkan pemograman pikiran alam bawah sadar, agar lebih mampu mengendalikan diri dalam

\section{ALTRUIS}


menghadapi pengaruh-pengaruh negatif arus informasi (internet dan gawai) dan pergaulan bebas.

\section{Realisasi Pemecahan Masalah}

Realisasi pemecahan masalah dalam kegiatan ini adalah lembaga yang terkait dengan institusi Muhammadiyah, yaitu SMK Muhammadiyah 2 Malang yang juga merupakan lembaga Muhammadiyah.

Alasan lain dari pemilihan lembaga ini sebagai tempat pengabdian adalah banyaknya temuan dan keluhan guru Bimbingan dan Konseling (BK) tentang perilaku berpacaran siswa-siswi yang semakin "berani" dan terdapat siswi yang hamil di luar nikah sehingga harus dikeluarkan dari sekolah serta semakin maraknya fenomena video porno dikalangan pelajar.

Fokus dari realisasi pemecahan masalah adalah memberikan pemahaman perilaku seksual remaja dan mengidentifikasinya serta melatih untuk mengendalikannya sehingga diharapkan para peserta lebih memahami bahaya perilaku seksual remaja dan memahami cara mengendalikannya.

\section{Khalayak Sasaran}

Waktu dan Tempat Kegiatan

Tempat kegiatan ini dilaksanakan di Aula SMK Muhammadiyah 2 Malang dilaksanakan setiap hari Sabtu dari bulan Desember tahun 2010 sampai Juni 2011 mulai pukul 08.00-11.30 WIB.

Sasaran Kegiatan

Sasaran kegiatan psikoedukasi perilaku seksual ini adalah siswa siswi kelas 2 SMK Muhammadiyah 2 Malang.

\section{Metode Yang Digunakan}

Metode yang digunakan dalam kegiatan ini terdiri dari dua bagian, yaitu; (1) Metode kegiatan ini dilakukan dengan metode dialog interaktif dan Focus Group Discussion (FGD). Dalam kegiatan ini diawali dengan eksplorasi pengetahuan dan pengalaman mengenai perilaku seksual remaja, cara ini dilakukan dengan metode brainstorming, FGD (Focus Group Discusion). Selanjutnya, kemudian diberikan film untuk diobservasi, peserta diajak presentasi, diskusi, tanya jawab dan diakhiri pemberian feed back dari fasilitator, (2) para siswa-siswi diajarkan pemograman pikiran alam bawah sadar, agar lebih mampu mengendalikan diri dalam menghadapi pengaruh-pengaruh negatif arus informasi (internet dan handphone) dan pergaulan bebas. 
Adapun beberapa materi pokok yang diberikan selama kegiatan berlangsung meiputi :

a. Tugas-tugas perkembangan remaja

b. Memahami makna "pacaran"

c. Memahami perilaku seksual

d. Mengendalikan perilaku seksual

Evaluasi dari pelaksanaan kegiatan pengabdian masyarakat ini dilaksanakan dalam bentuk:

1. Asesmen awal

Asesmen awal diberikan sebelum kegiatan dimulai. Asesmen ini dimaksudkan untuk mengetahui sejauh mana pemahaman mereka terhadap perilaku berpacaran dan asesmen ini dilakukan dengan menggunakan kuesioner.

2. Asesmen lanjut

Asesmen lanjut diberikan setelah kegiatan berakhir. Asesmen ini dimaksudkan untuk mengetahui sejauh mana pengaruh dari hasil kegiatan ini dengan cara menanyakan langsung dan tidak langsung (kuesioner).

\section{HASIL DAN PEMBAHASAN}

\section{Hasil Asesmen Awal}

Asesmen awal diberikan sebelum kegiatan dimulai. Asesmen ini dimaksudkan untuk mengetahui sejauh mana pemahaman mereka terhadap perilaku seksual berpacaran dan melakukan identifikasi sejauh mana perilaku seksual mereka selama berpacaran. Adapun hasil asesmen awal sebagaimana dibawah ini:

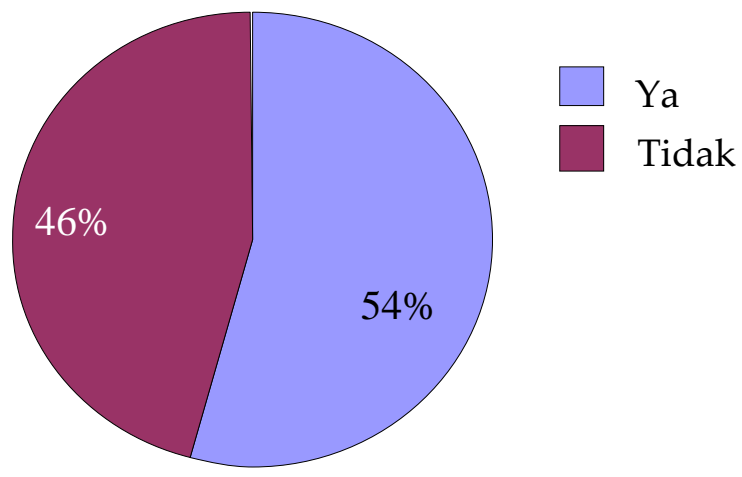

Grafik 1. Perilaku seksual dalam berpacaran

Dari hasil tersebut menunjukkan bahwa terdapat $54 \%$ siswa siswi mengetahui perilaku seksual dalam berpacaran dan $46 \%$ nya belum mengetahuinya.

\section{ALTRUIS}


ALTRUIS

ejournal.umm.ac.id/altruis

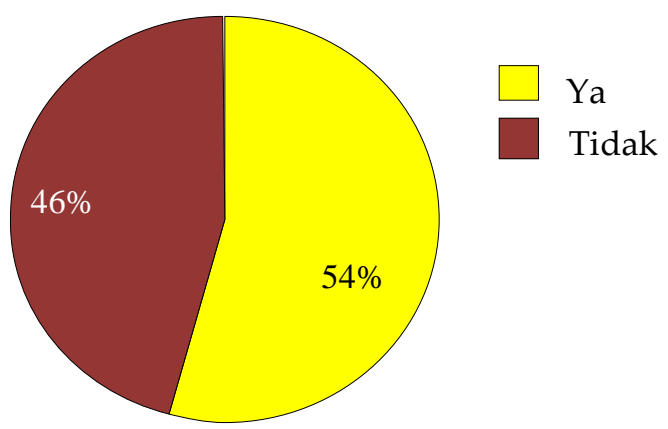

Grafik 2. Menjumpai perilaku seksual saat berpacaran

Dari hasil tersebut menunjukkan bahwa terdapat 54\% siswa siswi yang pernah menjumpai/menemui perilaku seksual dalam berpacaran dan $46 \%$ nya belum pernah.

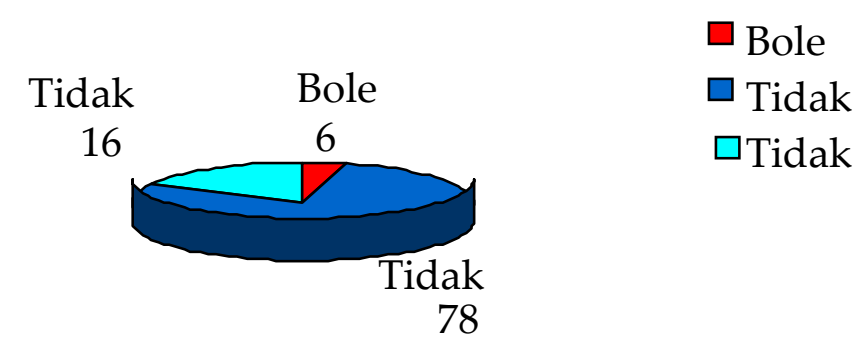

Grafik 3. Perilaku seksual dalam berpacaran

Dari hasil tersebut menunjukkan bahwa terdapat $78 \%$ siswa siswi yang memiliki pendapat tidak boleh melakukan perilaku seksual dalam berpacaran dan $16 \%$ tidak tahu, tetapi $6 \%$ nya menyatakan boleh dengan alasan tidak berlebihan dan sebagai bukti rasa cinta.

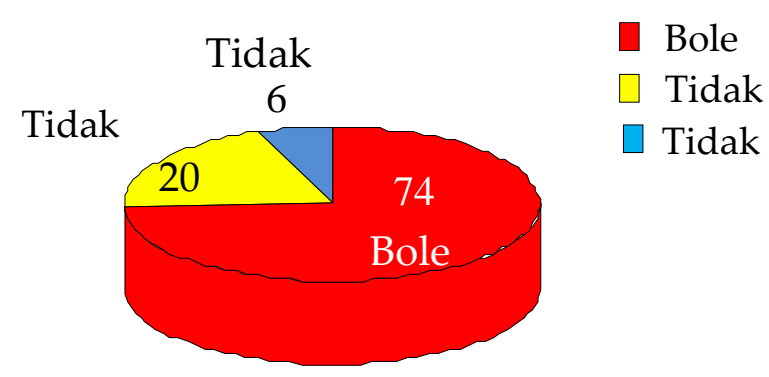

Grafik 4. Memperbolehkan berpacaran

Dari hasil tersebut menunjukkan terdapat $74 \%$ siswa siswi yang memiliki pendapat bahwa berpacaran itu boleh dengan alasan untuk motivasi belajar, untuk saling mengenal, menikmati masa muda asal positif, kalau tidak berpacaran sulit menemukan jodoh, seru, dan agar lebih mengenal 
sebelum menikah. Sebanyak 20\% yang mengatakan pacaran tidak boleh dengan alasan karena dilarang agama dan merusak konsentrasi sekolah dan sebanyak $6 \%$ tidak tahu.

Tabel 1. Makna pacaran

Berbagai makna pacaran

- Menjadikan seseorang menjadi senang dan tidak kesepian

- Tempat saling membantu dalam kehidupan

- Agar saling mengenal sifat

- Naluri dua insane

- Menjalin hubungan lebih dari pertemanan dan merasakan perasaan berbeda

- Hubungan yang saling mengisi, mensupport dan mengarahkkan yang baik

- Ketertarikan satu sama lain

- Rasa suka, sayang dan cinta

- Perasaan yang keluar dengan sendirinya

- Pertemanan yang membingungkan karena menyayangi orang lain lebih dari diri sendiri

- Proses menuju kedewasaan

- Berbagi kisah dan saling percaya

- Perbuatan yang mengundang nafsu birahi

Tabel 2. Perilaku yang pernah dilakukan saat pacaran

Perilaku yang dilakukan saat pacaran

1. Berpegangan tangan $74 \%$

2. Memeluk/dipeluk pundak/bahu $57 \%$

3. Memeluk/dipeluk pinggang $53 \%$

4. Mencium/dicium kening/pipi 53\%

5. Berciuman bibir $37 \%$

6. Mencium/dicium leher $16 \%$

7. Meraba/diraba tubuh dalam keadaan berpakaian $9 \%$

8. Meraba/diraba tubuh tanpa pakaian $9 \%$

\section{ALTRUIS}


9. Saling menempelkan alat kelamin dalam keadaan berpakaian $1 \%$

10. Saling menempelkan alat kelamin tanpa pakaian $1 \%$

11. Melakukan senggama/hubungan seksual 1\%

Dari persentase di atas dapat diuraikan bahwa perilaku seksual berpacaran remaja yang dominan atau sering dilakukan adalah berpegangan tangan sebanyak $74 \%$, berpelukan sebanyak $53-57 \%$, berciuman sebanyak $16-53 \%$, saling meraba sebanyak $9 \%$, dan lainnya sebanyak $1 \%$.

\section{Pelaksanaan Psikoedukasi}

Psikoedukasi pertama dilakukan menggunakan teknik ceramah dan dialog interaktif dengan tema psikologi perkembangan remaja (remaja dan permasalahannya). Pada sesi ini para peserta banyak yang bertanya seputar permasalahan remaja, seperti masalah yang berhubungan dengan lawan jenis (pacaran), hubungan sosial, dan hubungan dengan keluarga.

Psikoedukasi kedua dilakukan dengan teknik Focus Group Discussion. Pada pertemuan yang kedua ini temanya adalah memahami makna pacaran dan perilaku seksual. Pada kegiatan ini peserta dibagi menjadi tujuh kelompok masing-masing terdiri dari sepuluh orang. Selanjutnya masing-masing kelompok diminta untuk mendiskusikan tentang makna atau arti pacaran dan perilaku seksual dalam berpacaran serta dampak yang ditimbulkan. Kemudian masing-masing kelompok diminta untuk mempresentasikannya dalam bentuk slide.

Psikoedukasi ketiga dilakukan dengan teknik ceramah, dialog interaktif dan training, tema pada pertemuan ini adalah pengembangan dan pengendalian diri dari perilaku seksual. Pada saat dialog interaktif para peserta terlihat sangat antusias menanyakan berbagai masalah yang sedang mereka alami terkait pacaran.

Selanjutnya pada sesi training pengembangan dan pengendalian diri dengan menggunakan metode komunikasi alam bawah sadar (komunikasi hipnosis) dan dengan menggunakan teknik SEFT (Spiritual Emotional, Freedom Technique) serta melalui pendekatan religi. Pada sesi ini fasilitator mengajarkan teknik-teknik tersebut. 


\section{Asesmen lanjutan (Evaluasi)}

Pada pertemuan selanjutnya dilakukan evalusi atau asesmen lanjutan dengan cara menyebar kuesioner pada peserta psikoedukasi. Adapun hasil evaluasi sebagai berikut :

Kurang Senang

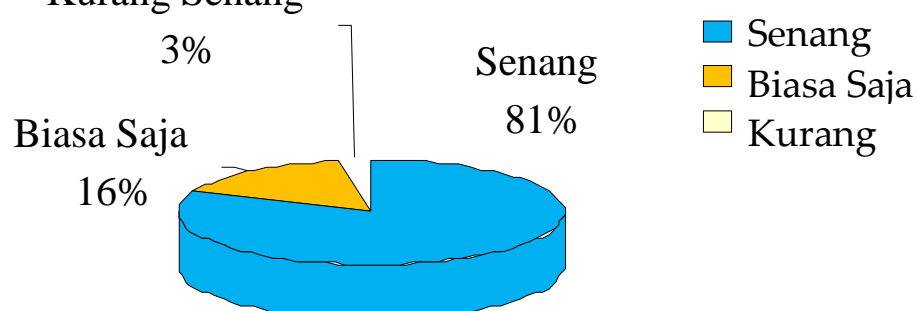

Grafik 5. Menyukai kegiatan psikoedukasi

Dari hasil tersebut menunjukkan bahwa terdapat sebanyak $81 \%$ peserta yang senang dengan kegiatan psikoedukasi tersebut, sebanyak $16 \%$ menganggap kegiatan tersebut biasa-biasa saja, dan sebanyak 3\% yang kurang tertarik dengan kegiatan tersebut.

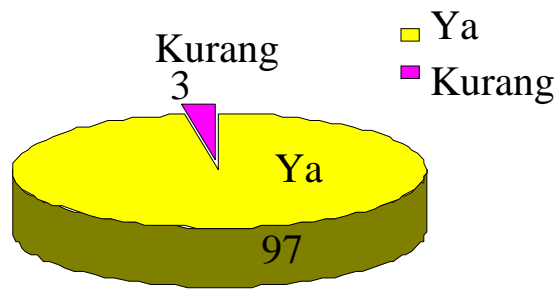

Grafik 6. Manfaat kegiatan psikoedukasi

Dari hasil tersebut menunjukkan bahwa terdapat sebanyak $97 \%$ peserta yang menganggap kegiatan ini bermanfaat dan selebihnya sebanyak $3 \%$ mengganggap kurang bermanfaat kegiatan ini.

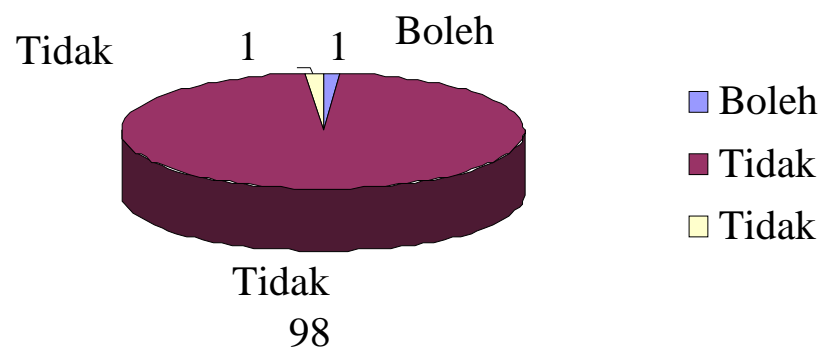

Grafik 7. Memperbolehkan perilaku berpacaran

Dari hasil tersebut menunjukkan bahwa terdapat sebanyak $98 \%$ peserta yang menyatakan perilaku seksual dalam berpacaran tidak diperbolehkan 
karena melanggar agama dan merugikan wanita, dan masing - masing sebanyak $1 \%$ menganggap boleh dan tidak tahu.

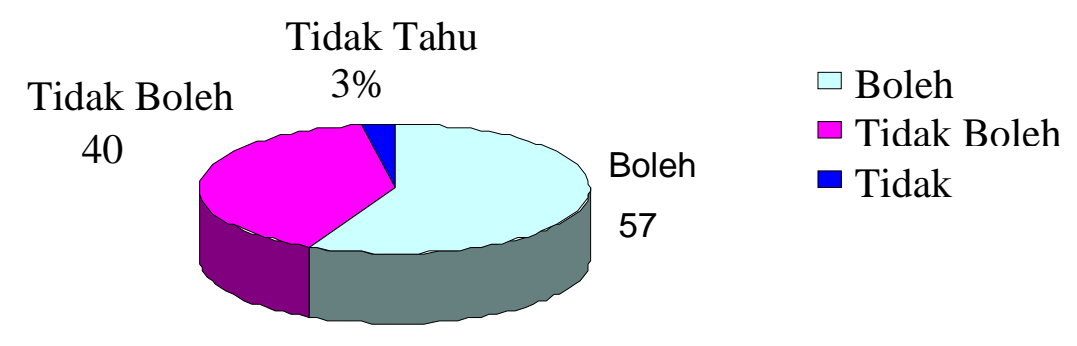

Grafik 8. Memperbolehkan pacaran

Dari hasil tersebut menunjukkan bahwa terdapat sebanyak 57\% peserta yang menyatakan pacaran diperbolehkan asalkan tidak terjerumus pada perbuatan negatif, sebanyak $40 \%$ peserta menyatakan tidak diperbolehkan berpacaran karena banyak negatifnya daripada positifnya dan agama pun melarang berpacaran, dan sebanyak $3 \%$ tidak tahu.

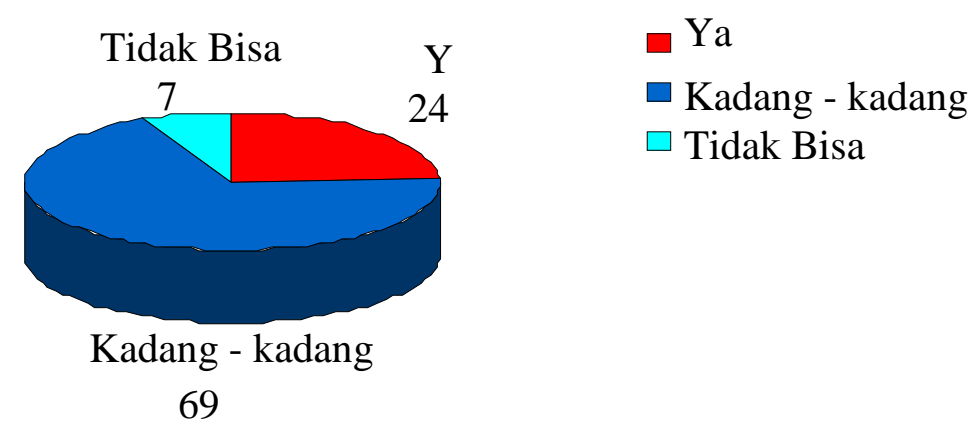

Grafik 9. Memanfaatkan teknik pengendalian diri yang telah diajarkan selama psikoedukasi

Dari hasil tersebut menunjukkan bahwa terdapat sebanyak $69 \%$ peserta yang menyatakan kadang-kadang dirinya dapat menggunakan teknik pengendalian diri, sebanyak $24 \%$ peserta menyatakan dapat menggunakan teknik tersebut, dan sebanyak $7 \%$ yang belum dapat menggunakan teknik tersebut.

\section{Kesimpulan}

\section{KESIMPULAN DAN SARAN}

Hasil dari kegiatan pengabdian masyarakat tentang Psikoedukasi Perilaku Seksual dalam Berpacaran di SMK Muhammadiyah 2 Malang dapat disimpulkan sebagai berikut: 
1. Pendidikan psikologis/mental bagi siswa - siswi sangat diperlukan khususnya terkait dengan hubungan lawan jenis dan pengendalian diri, hal ini sangat penting mengingat arus informasi kian hari kian mudah diakses sehingga tidak ada filter lain selain dirinya sendiri.

2. Melalui kegiatan ini dapat diketahui gambaran perilaku remaja terkait dengan perilaku seksual dalam berpacaran sehingga dapat dijadikan rujukan dalam memberikan pendidikan dan pembinaan bagi anak didik.

3. Melalui kegiatan ini dapat memahami mengenai arti remaja dengan berbagai permasalahanya, memahami makna pacaran dan perilaku-perilaku seksual dalam berpacaran sehingga pola pikir mengenai pacaran dapat dimodifikasi pada hal-hal yang lebih positif.

4. Para peserta memiliki teknik pengendalian diri yang sangat mudah untuk diterapkan dan memiliki manfaat yang luar biasa.

\section{Saran-Saran}

Saran untuk siswa - siswi

- Diharapkan kepada siswa - siswi SMK setelah mengikuti kegiatan ini dapat lebih menyaring berbagai arus informasi, baik yang bersumber dari media cetak ataupun elektronik terkait dengan pornografi.

- Lebih berhati - hati dan menjaga dalam hubungan dengan lawan jenis

- Senantiasa melatih teknik pengendalian diri

\section{Saran untuk Sekolah}

- Diharapkan sekolah terus dapat meningkatkan kerjasama dengan berbagai pihak untuk dapat mematangkan psikis/mental siswasiswinya.

- Memaksimalkan Bimbingan dan Konseling dalam usaha pengembangan dan pematangan psikologis siswa - siswi

\section{Saran untuk Pengabdian Masyarakat yang akan datang}

Diharapkan untuk membuat jadwal berkala untuk berpartisipasi dalam membantu pengembangan mental siswa - siswi, mengingat mereka akan langsung memasuki dunia kerja sehingga kondisi psikologis harus disiapkan sejak dini. 


\section{Daftar Pustaka}

Albin R.S. (2001). Bagaimana mengenal dan mengarahkan gangguan mental. Yogyakarta: Kanisius

Ali, M. Dkk. (2009). Psikologi remaja: Perkembangan peserta didik. Jakarta: PT. Bumi Aksara. Asror, M. (2003). Seks dalam bingkai islam. Surabaya: Jawara Surabaya

Bachtiar, A. (2004). Cinta remaja (mengungkap pola perilaku cinta remaja). Yogyakarta : ArRuszz Media

Chilman, C. S. (1983). Adolescent sexuality in a changing american society (social and psychological perspectives for the human services profession). New York : John Wiley and Son.

Diene M. et al,. (2002). Teen sexual behaviour. Applicability of the theory of reasoned action. Universitas of Washington. Journal of marriage and family. Vol. 64 : 885897.

Glevinno, A. (2008). Remaja dan seks. (http://public.kompasiana.com/).

Harris, R.H. (1994). Let' a talk about sex: Growing up, changing bodies, sex and sexual health. London: Walker Book

Knocx, D. (1998). Choice in relationships. St. Paul: Wes Publishing Company.

LP3ES. (1991). Seks dalam jaringan kekuasaan. Prisma. Edisi Juni

Master, W.H. Johson. V.E. Kolodny, R.C. (1992). Human sexuality. TK: Harper Collins Publisher.

Mottaghipour Y. (2005). The pyramid of family care a framework for family involvement with adulth mental health services. Toronto: Prentice Hall Health

Pasti, Y.P. (2008). Memotret perilaku seks remaja. (http://whandi.net/index.php)

Roy. (1999). Depresi dan solusinya. Yogyakarta. http://www.wordpress.com. Diperoleh tgl 19 Desember 2008

Sarwono, S. W. (2007). Psikologi remaja. Jakarta: PT. Raja Grafindo Persada Thorburg, H.D. (1982). Development in adolescence. California: Cole Publishing Company Widiyastuti, Y. Dkk. (2009). Kesehatan Reproduksi. Yogyakarta: Fitramaya. Widjayanto, I. (2003). Sex in the "kost". Yogyakarta: CV. Qalam 
PSIKOEDUKASI, PERILAKU SEKSUAL REMAJA

ALTRUIS 